\title{
KAJIAN METODE-KONSEP DESAIN BERDASARKAN PROBLEM SEEKING
} (Studi Kasus: Hunian Arsitek Akademisi di Kota Malang)

\author{
Redi Sigit Febrianto \\ Dosen Prodi Arsitektur Institut Teknologi Nasional (ITN) Malang \\ e-mail: redi_sigit@lecturer.itn.ac.id \\ Bayu Teguh Ujianto \\ Dosen Prodi Arsitektur Institut Teknologi Nasional (ITN) Malang \\ Bambang Joko Wiji Utomo \\ Dosen Prodi Arsitektur Institut Teknologi Nasional (ITN) Malang
}

\begin{abstract}
ABSTRAK
Kajian ini merupakan bagian studi literatur mengenai metode dan konsep desain dari oleh William M. Peña dan Steven A. Parshall, yaitu tentang Problem Seeking: An Architectural Programming Primer. Penelitian mengenai metode dan konsep desain arsitektural sudah banyak dibahas. Namun pada penelitian ini mengkhususkan diri mengkaji 11 objek amatan berdasarkan problem seeking: an architectural programming primer. Rancangan penelitian bersifat kualitatif, sedangkan strategi penelitian berjenis deskriptif. Metode pengumpulan data bersifat eksploratif sekaligus eksplanatif. Metode analisis yang dipakai adalah: (1) analisis tematik dan (2) analisis induktif. Rumusan masalah pada kajian ini adalah apa saja objek amatan pembentuk metode desain problem seeking? Tujuan kajian ini adalah membentuk digram mengenai metode desain problem seeking. Simpulan pada kajian ini yaitu terbentuknya diagramatik 11 objek amatan dan 22 indikator dari metode dan konsep desain
\end{abstract}

Kata kunci : metode-konsep desain, problem seeking, analisis tematikinduktif

\section{PENDAHULUAN}

Penelitian mengenai metode dan konsep desain hunian khususnya arsitek praktisi (anggota IAI) sudah banyak diteliti (Hindarto, 2017), namun penelitian mengenai metode dan konsep desain hunian arsitek akademisi (dosen arsitektur) di kota Malang masih sangat jarang untuk dibahas. Oleh sebab itu penelitian ini dianggap penting oleh penulis.

Studi tentang metode desain sudah dimulai sejak tahun 1950, diawali dari meningkatnya kompleksitas dalam produk-produk industry (Linden, Lacerda, \& Aguiar, 2011). Tujuan dari mempelajari metode desain pada kajian ini adalah untuk mengembangan model desain dan mencerminkan periode di mana desain tersebut dikembangkan. Tujuan mempelajari konsep desain-sebagai tahapan terpenting dan terumit dalam keseluruhan proses 
desain-yaitu sebagai panduan semua keputusan desain selanjutnya. Konsep desain mengintegrasikan visi dan misi dengan tapak untuk mencapai tujuan akhir desain.

Namun tujuan holistik pada kajian ini adalah untuk untuk mendapatkan wawasan atau kebenaran esensial dari cara jejak telusur (audit trail) desain dan ide pokok (main idea) desain. William M. Peña dan Steven A. Parshall mengungkapkan-pada bukunya yang berjudul: Problem Seeking: An Architectural Programming Primer-bahwa metode desain seharusnya sederhana dan sekaligus komprehensif. Cukup "sederhana" sehingga dapat diaplikasikan lagi pada desain bangunan lain dan cukup "komprehensif" sehingga dapat mencakup faktor-faktor yang mempengaruhi desain bangunan lain. Pada kajian ini terdapat total 11 objek amatan dan 22 indikator. Terdiri dari 9 objek amatan yang mencakup metode desain dan 2 objek amatan yang mencakup konsep desain.

\section{TINJAUAN PUSTAKA}

\subsection{Metode Desain}

Metode desain adalah: (1) kunci untuk mendapatkan wawasan atau kebenaran esensial yang unik khususnya pada saat proses pengumpulan ide dan proses analisis ide (Ali, 2017; Jones, 1990)); (2) pengenalan cara dan urutan mendesain serta membangun metode berpikir yang sesuai dengan proses permasalahan desain, yakni dengan metode pemecahan masalah. Desain yang baik, umumnya memiliki metoda desain yang baik, yaitu dapat dicari jejak telusurnya; (3) kunci untuk mendapatkan wawasan atau kebenaran esensial yang unik menghasilkan lebih banyak solusi holistik untuk mencapai pengalaman yang lebih baik untuk pengguna dengan produk, jasa, lingkungan dan mengandalkan sistem mereka (Anonim, 2011).

William M. Peña dan Steven A. Parshall-pada bukunya yang berjudul: Problem Seeking: An Architectural Programming Primermengungkapkan terdapat 11 indikator yang salin berlawanan dalam mempelajari metode desain. Pada kajian metode desain, terdapat 9 indikator yaitu: (1) masalah-solusi; (2) algoritmika-heuristik; (3) feedforwardfeedback; (4) seni-sains; (5) abstrak-konkrit; (6) kompleks-simple; (7) holistik-atomistik; (8) obyektif-subyektif; (9) logis-intuitif.

\subsection{Konsep Desain}

Konsep desain adalah: (1) kunci untuk mendapatkan wawasan atau kebenaran esensial yang unik tentang proses berpikir dan fase desain khususnya merujuk pada ide utama (Ali, 2017; Jones, 1990)); (2) cara arsitek menanggapi sebuah kebutuhan desain dengan menerjemahkan ideide yang abstrak menjadi rancangan bangunan yang bisa terwujud. Di dalam konsep ini akan tertuang semua ide-ide dasar, rencana dan tujuan, pemikiran baru dan unik berdasarkan pendapat, keyakinan, teori, keinginan, 
dan kebutuhan home-owner (Meilanita, 2017). Pada kajian konsep desain, terdapat 2 indikator yaitu: (10) komprhensif-singular; (11) analisis- sintesis.

\subsection{Problem seeking Vs Problem solving}

Definisi programming berbeda dengan desain. Programming adalah sebuah proses usaha, desain adalah usaha kreatif, sebuah proses yang mengarah pada sebuah statement dari sebuah permasalahan arsitektural dan kebutuhan akan solusi. Jika programming berusaha mencari permasalahan (problem seeking), maka desain berusaha memecahkan permasalahan (problem solving) (Pena \& Parshall, 2001).

\section{METODE PENELITIAN}

\subsection{Strategi Penelitian}

Penelitian ini menggunakan strategi yang bersifat deskriptif / naratif. Penelitian naratif merupakan strategi penelitian di mana di dalamnya peneliti menyelidiki kehidupan individu-individu dan meminta seorang atau sekolompok individu untuk menceritakan kehidupan mereka. Informasi ini kemudian diceritakan kembali oleh peneliti dalam kronologi naratif. Di akhir tahap penelitian, peneliti harus menggabungkan dengan gaya naratif pandangan-pandangannya tentang kehidupan partisipan dengan pandangan-pandangannya tentang kehidupan peneliti sendiri (Clandinin \& Connelly, 2000 dalam Creswell, 2012).

\subsection{Metode Pengumpulan Data}

Metode pengumpulan data bersifat kualitatif (bukan kuantitatif). Tujuan penelitian kualitatif pada umumnya mencakup informasi tentang fenomena utama yang dieksplorasi dalam penelitian, partisipan penelitian, dan lokasi penelitian. Tujuan penelitian kualitatif juga bisa menyatakan rancangan penelitian yang dipilih. Tujuan ini ditulis dengan istilah-istilah "teknis" penelitian yang bersumber dari bahasa penelitian kualitatif (Schwandt, 2007 dalam Creswell, 2012).

Sampel pada saat pengumpulan data dilakukan pada 10 hunian arsitek akademisi di kota Malang, namun sering dengan klasifikasi berdasarkan konsep desainnya direduksi menjadi 3 (tiga) hunian, yaitu: (1) berdasarkan konsep rasional, (2) berdasarkan konsep tradisional / konvensional (3) berdasarkan konsep gabungan.

Ketiga identitas arsitektur akademisi tersebut disamarkan, yaitu: Dosen $A$ (BTU) merupakan dosen struktur dan dosen perancangan di sebuah PTS di Malang; dosen B (DS) adalah dosen MK struktur, perancangan dan utilitas di sebuah PTS di Malang; dosen C adalah dosen MK sains dan teknologi bangunan di sebuah PTN di Malang. 
Terdapat 4 jenis metode pengumpulan data pada kajian ini yaitu : (1) survei arsitektural, (2) pengukuran arsitektural, (3) sketsa arsitektural dan (4) dokumentasi arsitektural

\subsection{Metode Analisis Data}

Analisis yang digunakan pada kajian ini adalah: (1) analisis tematik dan (2) analisis induktif. Analisis tematik berfungsi untuk merangkai indikator hingga menentukan objek amatan, merangkai tema, membentuk kategori, sampai akhirnya terbentuk konsepdalam bentuk diagram. Analisis induktif berfungsi untuk merangkai indikator, objek amatan, tema, kategori hingga membentuk konsep namun dalam bentuk narasi.

Analisis tematik merupakan salah satu cara untuk: (a) mengupas secara rinci data-data kualitatif yang mereka miliki guna menemukan keterkaitan pola-pola dalam sebuah fenomena dan menjelaskan sejauhmana sebuah fenomena terjadi melalui kacamata peneliti (Fereday \& Muir-Cochrane dalam Heriyanto, 2018); (b) menganalisa data dengan tujuan untuk mengidentifikasi pola atau untuk menemukan tema melalui data yang telah dikumpulkan oleh peneliti (Braun \& Clarke dalam Heriyanto, 2018); (c) dasar atau pondasi untuk kepentingan menganalisa dalam penelitian kualitatif (Heriyanto, 2018 ).

Motode analisis bersifat induktif diilustrasikan sebagai: (a) usaha peneliti dalam mengolah secara berulang-ulang; (b) membangun serangkaian konsep yang utuh; (c) mencari indikator dan objek amatan; (d) membangun tema-tema dan kategori hingga; (e) membentuk konsep pada bagian akhir (Creswell, 2016).

Metode analisis diutamakan berdasarkan 3 konsep desain utama berdasarkan Hosein., et al (2008) dan Taschen (2009), yaitu: tipe tradisional (black-box), rasional (glass-box)

Dijelaskan bahwa proses berpikir dan fase desain dibagi dua tipe, yakni tipe tradisional (black-box) dan rasional (glass-box) (Jones, 1990); Berbeda dengan Hosein et al (2008) yang membagi menjadi tiga yaitu: black-box (proses tidak ditunjukkan), glass-box (proses ditunjukkan) and open-box (proses yang lebih interaktif). Secara arsitektural proses desain akan membentuk dua kubu ekstrem tentang proses desain yaitu: tipe tradisional (black-box) dan rasional (glass-box), namun Bjarke Ingels (2009) berusaha menjembatani keduanya sehingga disebut sebagai proses desain jenis pragmatic utopianism (Taschen, 2009) atau open-box (Hosein, Aczel, Clow, \& Richardson, 2008). 


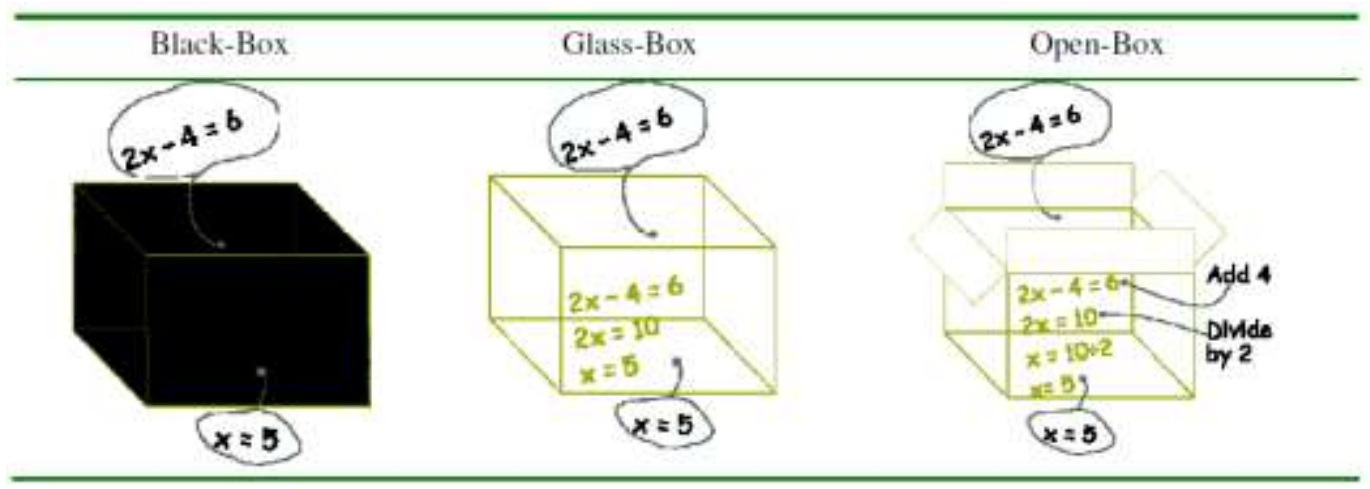

Gambar 1. Perbandingan tiga konsep desain

Sumber: (Hosein, Aczel, Clow, \& Richardson, 2008)

\section{HASIL DAN PEMBAHASAN}

\subsection{Analisis Sumber Desain}

Analisis sumber desain memiliki dua indikator yaitu: 1) berawal dari intuisi-kognisi; 2) masalah-solusi. Pada sub ini akan dianalisis 3 (tiga) pewakilan hunian arsitek akademisi (dosen arsitektur).



Gambar 2. Indikator Sumber Desain: Masalah-Solusi Sumber: Pena \& Parshall (2001)

Sumber desain hunian dosen arsitek $A$ berasal dari adanya sebuah masalah yaitu: permasalahan tentang pengaturan ruangan berdasarkan ukuran bahan. Pembentukan ruangan umumnya berbentuk ukuran berdasarkan standart. Namun pada hunian dosen A permasalahan pembentukan ruangan berawal dari ukuran bahan asli, yang nantinya akan membentuk ukuran ruangan. Sumber desain yang berawal dari permasalahan umumnya memiliki sifat kognisi.

Sumber desain hunian dosen arsitek B berasal dari solusi yaitu: berdasarkan kesinambungan penggunaan lahan eksisting yang berkontur. Lahan hunian dosen B merupakan lahan yang memiliki kontur hingga 1,5 m. Oleh sebab itu dosen B berkeinginan mendaya gunakan kontur tersebut agar memiliki tingkat privasi ruang yang tinggi, mendayagunakan ruang primer sebagai ruang utama dan penghawaan dan pencahayaan ruang yang 
optimal. Sumber desain yang berawal dari solusi umumnya memiliki sifat intuitif.

Sumber desain hunian dosen arsitek $\mathrm{C}$ berawal dari permasalahan sekaligus berorientasi solusi yaitu: berdasarkan pendayagunaan arsitektur tropis dengan analogi kapal. Permasalahan pada hunian dosen $\mathrm{C}$ adalah penghawaan dan pencahayaan yang kurang optimal karena berada di daerah permukiman padat. Solusi dari hunian dosen $C$ adalah analogi kapal sebagai solusi untukmemperkuat daya guna arsitektur tropis. Sumber desain yang berawal dari permasalahan umumnya memiliki sifat kognisi.

\subsection{Analisis Waktu Desain}

Analisis waktu dalam mendesain memiliki dua indikator yaitu: 1) bersifat cepat-lambat; 2) berdasarkan algoritmika-heuristik. Pada sub ini akan dianalisis 3 (tiga) pewakilan hunian arsitek akademisi (dosen arsitektur).

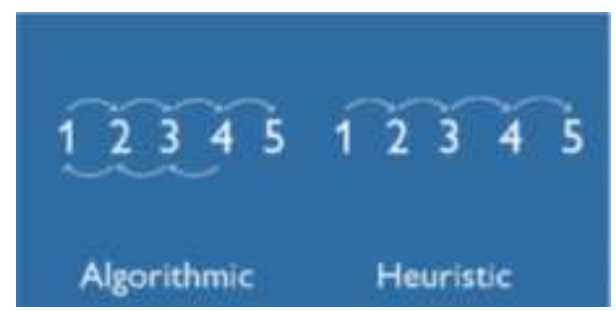

Gambar 3. Indikator Waktu Desain: Algoritmika-Heuristik Sumber: Pena \& Parshall (2001)

Waktu desain hunian dosen arsitek A proses desainnya bersifat algoritmika dan cenderung lambat, prosesnya berulang-ulang dan cenderung maju-mundur. Proses desain berjalan lambat dikarenakan sumber desainnya berasal dari penyesuaian ukuran bahan dalam membentuk ruangan. Sehingga ruang-ruang yang terbentuk ukurannya tidak berbentuk bulat, melainkan terbentuk karena ukuran bahan. Dalam hal ini ukuran ruangan terbentuk dari ukuran keramik $60 \times 60 \mathrm{~cm}$. Waktu desain yang lambat cenderung besifat algoritmika.

Waktu desain hunian dosen arsitek B proses desainnya bersifat heuristik dan cenderung cepat, prosesnya tidakberulang-ulang dan cenderung bersifat maju. Proses desain berjalan cepat dikarenakan sumber desainnya berorientasi dari solusi yaitu penyesaian lahan berkontur $1,5 \mathrm{~m}$ pada area permukiman padat. Waktu desain yang cepat cenderung besifat heuristika.

Waktu desain hunian dosen arsitek $\mathrm{C}$ prosesnya bersifat algoritmika sekaligus heuristik. Proses desain cenderung relatif lambat, namun juga tidak terlalu cepat, prosesnya maju - mundur. Hal tersebut diakibatkan oleh permasalahan pada hunian dosen $\mathrm{C}$ adalah penghawaan dan pencahayaan yang kurang optimal karena berada di daerah permukiman padat. Solusi dari hunian dosen $\mathrm{C}$ adalah analogi kapal sebagai solusi untukmemperkuat daya 
guna arsitktur tropis. Waktu desain yang tidak cepat namun juga tidak lambat, cenderung besifat heuristika sekaligus algoritmika.

\subsection{Analisis Urutan Desain}

Analisis urutan dalam mendesain memiliki dua indikator yaitu: 1) sistematis - acak; 2) feedforward-feedback. Pada sub ini akan dianalisis 3 (tiga) pewakilan hunian arsitek akademisi (dosen arsitektur).

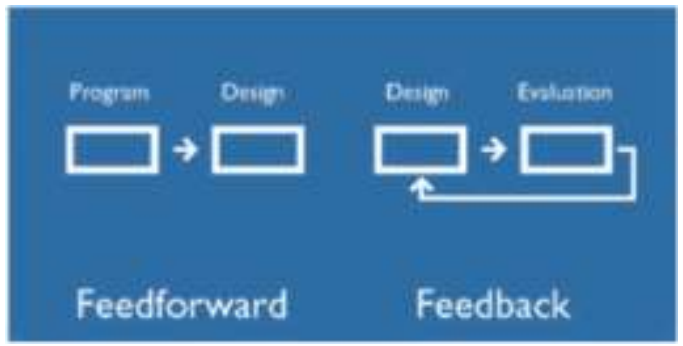

\section{Gambar 4. Indikator Urutan Desain: Feedforward - Feedback Sumber: Pena \& Parshall (2001)}

Urutan desain hunian arsitek tipe A prosesnya sistematis. Dikatakan sistematis sebab dosen A sudah mendesain ruang sejak awal dengan hatihati, agar efektif dan tidak mmembentuk proses yang berbelit-belit. Dosen $\mathrm{A}$ menghindari adanya revisi desain pada saat pengeerjaan di lapangan. Dikarenakan perubahan saat di lapangan akan mengubah rencana awal yang sudah disusun secara matang. Urutan desain berbentuk sistematis umumnya bersifat feedforward.

Urutan desain hunian arsitek tipe B prosesnya acak. Dikatakan acak karena desain mengalami berbagai perubahan saat di lapangan. Sehingga gambar desain awal dengan yang ada di lapangan. Dosen B menginginkan perubahan pada saat di lapangan, dengan pertimbangan desain yang menarik saat melihat kondisi aslinya. Urutan desain berbentuk acak umumnya bersifat feedback.

Urutan desain hunian arsitek tipe $\mathrm{C}$ prosesnya relatif sistematis dan juga cenderung acak. Dikatakan demikian karena dosen tipe $C$ tetap mematuhi rencana desain yang semula dibuat namun juga melakukan beberapa perubahan dengan pertimbangan estetika desain. Urutan desain berbentuk acak namun juga sistematis, umumnya bersifat gabungan antara feedback dan feedforward.

\subsection{Analisis Figur Desain}

Analisis figur dalam mendesain memiliki dua indikator yaitu: 1) ada figure desain - tidak ada figur desain; 2) berorientasi pada seni-sains. . 
Pada sub ini akan dianalisis 3 (tiga) pewakilan hunian arsitek akademisi (dosen arsitektur).



Gambar 5. Indikator figur desain: Seni vs Sains Sumber: Pena \& Parshall (2001)

Figur Desain Hunian Arsitek A tidak bergantung figure arsitek spesifik tertentu, namun bergantung pada sains. Ketergantungannya terhadap sains menyebabkan urutan desain hunian arsitek tipe A prosesnya sistematis.

Figur desain hunian arsitek B tidak bergantung figure arsitek tertentu, sehingga bergantung pada seni. Tanpa adanya figure arsitek dalam mendesain, urutan desain hunian arsitek tipe B prosesnya acak. Dikatakan acak karena desain mengalami berbagai perubahan saat di lapangan. Sehingga gambar desain awal dengan yang ada di lapangan. Dosen B menginginkan perubahan pada saat di lapangan, dengan pertimbangan desain yang menarik saat melihat kondisi aslinya.

Figur desain hunian arsitek $C$ cenderung bergantung figure arsitek tertentu, namun tidak terlalu mengikuti pakem yang ada dari figure tersebut. Desain hunian arsitek $C$ juga bergantung pada sains sekaligus seni. Hal tersebut mengakbatkan prses desain berlangsung sangat dinamis. Sehingga menghasilkan proses desain yang cukup lama karena harus megadaptasi sains, namun juga sangat memperhatikan seni.

\subsection{Analisis Mood Booster Desain}

Analisis mood booster dalam mendesain memiliki dua indikator yaitu: 1) fisik - non fisik; 2) bersifat abstrak - konkrit.

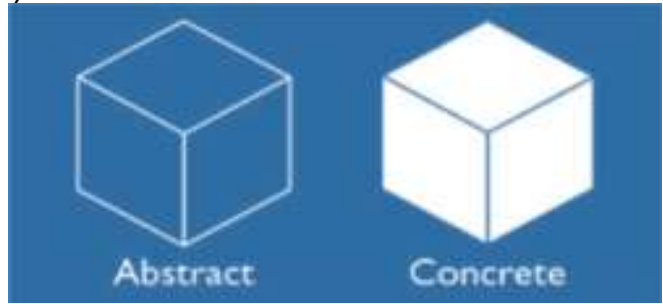

Gambar 6. Indikator mood booster desain: Abstrak - Konkrit Sumber: Pena \& Parshall (2001)

Desain hunian dosen arsitek A tidak menggunakan mood booster namun hasil desainnya bersifat konkrit. Indikator mood booster bersifat 
konkrit dalam mendesain dapat dikategorikan sebagai indikator yang berasal dari literature, berorientasi pada masalah dan cenderung lebih stabil. Desain cenderung untuk konstan yang waktunya relatifcepat, tidak berbelit-belit dan cenderung bersifat menyelesaikan masalah.

Desain hunian dosen arsitek B tidak menggunakan mood booster, namun hasil desainnya bersifat konkrit. Indikator mood booster bersifat konkrit dalam mendesain dapat dikategorikan sebagai indikator yang berasal dari literature, berorientasi pada masalah dan cenderung lebih stabil. Desain cenderung untuk konstan yang waktunya relatifcepat, tidak berbelit-belit dan cenderung bersifat menyelesaikan masalah.

Desain hunian dosen arsitek $\mathrm{C}$ tidak menggunakan mood booster, namun hasil desainnya bersifat konkrit. Indikator mood booster bersifat konkrit dalam mendesain dapat dikategorikan sebagai indikator yang berasal dari literature, berorientasi pada masalah dan cenderung lebih stabil. Desain cenderung untuk konstan yang waktunya relatifcepat, tidak berbelit-belit dan cenderung bersifat menyelesaikan masalah.

\subsection{Analisis Gaya Desain}

Analisis gaya desain memiliki dua indikator yaitu: 1) berbasis tradisional - modern; 2) bersifat kompleks - sederhana.

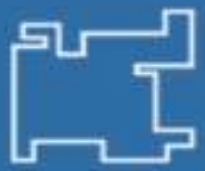

Complexity

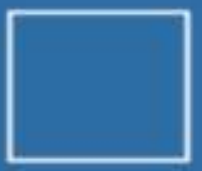

Simplicity

Gambar 7. Indikator gaya desain: Kompleks - Simpel

Sumber: Pena \& Parshall (2001)

Gaya Desain Hunian Dosen Arsitek A bersifat gabungan, yaitu proses berpikir yaitu kompleks sekaligus sederhana mulai dari: sistem ruang dalam, sistem ruang luar, sistem struktur bangunan, sistem tampilan bangunan, sistem bentuk bangunan, sistem pola ruang.

Gaya Desain Hunian Dosen Arsitek A bersifat gabungan, yaitu proses berpikir yaitu kompleks sekaligus sederhana mulai dari: sistem ruang dalam, sistem ruang luar, sistem struktur bangunan, sistem tampilan bangunan, sistem bentuk bangunan, sistem pola ruang.

Gaya Desain Hunian Dosen Arsitek C bersifat gabungan, yaitu proses berpikir yaitu kompleks sekaligus sederhana mulai dari: sistem ruang dalam, sistem ruang luar, sistem struktur bangunan, sistem tampilan bangunan, sistem bentuk bangunan, sistem pola ruang. 


\subsection{Analisis Literatur Desain}

Analisis literatur dalam mendesain memiliki dua indikator yaitu: 1) literatur baru-literatur lama; 2) bersifat holistik - atomistik.

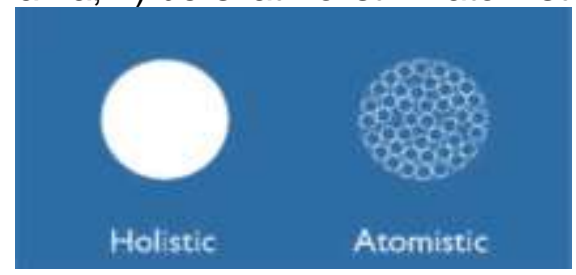

Gambar 8. Indikator literatur desain: Holistik - Atomistik

Sumber: Pena \& Parshall (2001)

Desain hunian dosen Arsitek A menggunakan literatur dan desainnya berawal dari pengetahuan yang bersifat holisitik. Indikator menggunakan literatur dalam mendesain dapat didefinisikan sebagai pengaplikasian teori terbaru yang dapat diterapkan pada sistem ruang dalam, sistem ruang luar, sistem struktur bangunan, sistem tampilan bangunan, sistem bentuk bangunan, sistem pola ruang.

Desain hunian dosen Arsitek B menggunakan literatur dan desainnya berawal dari pengetahuan yang bersifat holisitik. Indikator menggunakan literatur dalam mendesain dapat didefinisikan sebagai pengaplikasian teori terbaru yang dapat diterapkan pada sistem ruang dalam, sistem ruang luar, sistem struktur bangunan, sistem tampilan bangunan, sistem bentuk bangunan, sistem pola ruang.

Desain hunian dosen Arsitek $C$ menggunakan literatur dan desainnya berawal dari pengetahuan yang bersifat holisitik. Indikator menggunakan literatur dalam mendesain dapat didefinisikan sebagai pengaplikasian teori terbaru yang dapat diterapkan pada sistem ruang dalam, sistem ruang luar, sistem struktur bangunan, sistem tampilan bangunan, sistem bentuk bangunan, sistem pola ruang.

\subsection{Analisis Media Desain}

Analisis media dalam mendesain memiliki dua indikator yaitu: 1) digital-manual \& 2) obyektif-subyektif.



Gambar 9. Indikator literatur desain: Obyektif - Subyektif Sumber: Pena \& Parshall (2001) 
Media desain hunian dosen arsitek A dalam merancang huniannya menggunakan media digital dan cenderung bersifat obyektif. Indikator "obyektif" dapat didefinisikan sebagai penggunaan media digital sebagai alat bantu dalam mendesain. Dengan penggunaan produk digital, konsep desain dapat disebarluaskan dan dinilai secara obyektif oleh pihak lain. Indikator "obyektif" dapat didefinisikan sebagai penggunaan media digital sebagai alat bantu dalam mendesain. Dengan penggunaan produk digital, konsep desain dapat disebarluaskan dan dinilai secara obyektif oleh pihak lain.

Media desain hunian dosen arsitek B dalam merancang huniannya menggunakan media manual dan cenderung bersifat subyektif. Namun dalam proses perancangan akhir, gambar kerja digbentu melalui media digital atas tuntutan teknologi. Indikator "subyektif" dapat didefinisikan sebagai penggunaan media manual sebagai alat bantu dalam mendesain. Dengan penggunaan desain manual, konsep desain cenderung sulit untuk disebarluaskan dan hanya dinilai secara subyektif oleh si perancang.

Media desain hunian dosen arsitek $C$ dalam merancang huniannya menggunakan media digital sekaligus manual. Sehingga hasil desainnya dapat bersifat subyektif sekaligus obyektif. Indikator "obyektif" dapat didefinisikan sebagai penggunaan media digital sebagai alat bantu dalam mendesain. Dengan penggunaan produk digital, konsep desain dapat disebarluaskan dan dinilai secara obyektif oleh pihak lain. Indikator "subyektif" dapat didefinisikan sebagai penggunaan media manual sebagai alat bantu dalam mendesain. Dengan penggunaan desain manual, konsep desain cenderung sulit untuk disebarluaskan dan hanya dinilai secara subyektif oleh si perancang.

\subsection{Analisis Waktu Pengerjaan}

Analisis waktu pengerjaan memiliki dua indikator yaitu: 1) langsung bertahap; 2) logis - intuitif.



Gambar 10. Indikator waktu pengerjaan: Logis - Intuitif Sumber: Pena \& Parshall (2001)

Waktu pengerjaan hunian dosen arsitek $A$ membutuhkan waktu yang cepat, dan didesain berdasarkan logika. Indikator secara "logis" dapat didefinisikan sebagai proses berpikir yang bersifat konkrit dalam mendesain dapat dikategorikan sebagai indikator yang berasal dari literature, 
berorientasi pada masalah dan cenderung lebih stabil. Desain cenderung untuk konstan yang waktunya relatifcepat, tidak berbelit-belit dan cenderung bersifat menyelesaikan masalah.

Waktu pengerjaan hunian dosen arsitek B membutuhkan waktu yang bertahap, namun didesain berdasarkan intuisi. Indikator waktu pengerjaan "bertahap" dapat didefinisikan sebagai proses berpikir abstrak dalam mendesain dapat dikategorikan sebagai indikator berasal dari intuisi, beroentasi pada solusi dan cenderung labil. Desain cenderung untuk berubah-ubah yang waktunya lama, berbelit-belit dan cenderung terjebak dalam detail.

Waktu pengerjaan hunian dosen arsitek $\mathrm{C}$ membutuhkan waktu yang bertahap, namun didesain berdasarkan intuisi. Indikator waktu pengerjaan "bertahap" dapat didefinisikan sebagai proses berpikir abstrak dalam mendesain dapat dikategorikan sebagai indikator berasal dari intuisi, beroentasi pada solusi dan cenderung labil. Desain cenderung untuk berubah-ubah yang waktunya lama, berbelit-belit dan cenderung terjebak dalam detail.

\subsection{Analisis Lingkup Desain}

Analisis lingkup desain memiliki dua indikator yaitu: 1) ruang dalam ruang luar; 2) komprehensif - singular.Lingkup desain hunian dosen arsitek A memiliki lingkup desain yang bersifat singular, yaitu mengkhususkan diri pada: 1) sistem struktur bangunan, 2) sistem tampilan bangunan dan 3) sistem bentuk bangunan.



Gambar 11. Indikator Lingkup Desain: Komprhensif - Singular Sumber: Pena \& Parshall (2001)

Lingkup desain hunian dosen arsitek $A$ memiliki lingkup desain yang bersifat komprehensif, yaitu berusaha mendesain secara menyeluruh pada 6 sistem yang ada yaitu: 1) sistem ruang luar, 2) sistem ruang dalam, 3) sistem struktur bangunan,4) sistem tampilan bangunan, 5) sistem bentuk bangunan dan 6) sistem penataan ruang.

Lingkup desain hunian dosen arsitek $\mathrm{C}$ memiliki lingkup desain yang bersifat komprehensif, yaitu berusaha mendesain secara menyeluruh pada 6 sistem yang ada yaitu: 1) sistem ruang luar, 2) sistem ruang dalam, 3) 
sistem struktur bangunan,4) sistem tampilan bangunan, 5) sistem bentuk bangunan dan 6) sistem penataan ruang.

\subsection{Analisis Konsep Desain}

Analisis konsep desain memiliki tiga indikator yaitu: 1) rasional tradisional; 2) analisis - sintesis.

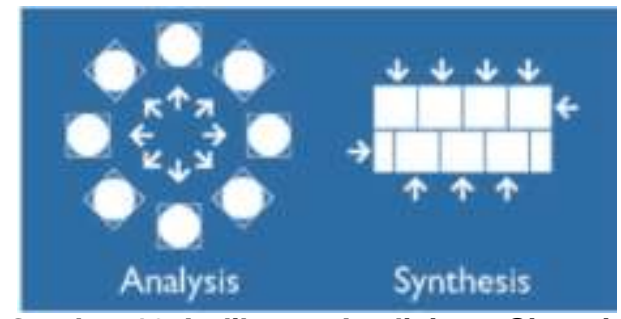

Gambar 12. Indikator: Analisis vs Sintesis

Sumber: Pena \& Parshall (2001)

Konsep desain hunian dosen arsitektur A bersifat rasional. Proses berpikir rasional ini, dilakukan logis oleh desainer terhadap karya yang dibuat, konsep desain yang dibuat tidak datang secara spontan, analisa dalam merancang dilakukan dengan lengkap, melalui proses pengujian, desain memiliki makna dan logis, strategi ditentukan dengan sangat matang. Dalam metode desain rasional, desainer/ arsitek tidak selalu melakukan pembangunan terhadap karya mereka, namun karya yang mereka buat, juga dapat dibangun oleh orang lain. Berbeda dengan metode desain dengan metode tradisional bahwasanya desainer adalah pelaku pembangunannya.

Konsep desain hunian dosen arsitektur B bersifat tradisional. Proses berpikir tradisional ini, dilakukan secara spontanitas oleh desainer suatu karya. Ide datang bisa dari mana saja dan kapan saja untuk membuat suatu karya. Beberapa ciri-ciri proses berpikir tradisional adalah: ide kreatifitas rancangan tidak jelas datang dari mana konsepnya, sukar untuk menjelaskan konsep yang didapat, proses kreatif satu rancangan tidak dapat terlihat jelas, hasil suatu karya tidak dapat di-kritik, dan kapasitas produksi yang bergantung kepada ketersediaan waktu, mood, dan imajinasi si perancang (Jones, 1990).

Konsep desain hunian dosen arsitektur $\mathrm{C}$ bersifat terbuka. Proses berpikir terbuka ini merupakan gabungan dan berusaha menjembatani keduanya proses berpikir rasional dan tradisiona. Proses berpikir terbuka ini mengambil sumber ide berasal dibentuk dari unsur-unsur sosial, ekonomi, (termasuk politik) dan juga lingkungan yang saat itu berkembang di masyarakat (arsitektur kiwari). Proses desain ditunjukkan sedemikian rupa secara interaktif sehingga bersifat pragmatik sehingga dapat membentuk sebuah utopia. Proses berpikir terbuka ini bersifat inklusif (menyeluruh atau 
mengakomodir semua elemen) bukan eksklusif (hanya mengakomodir satu elemen atau khusus).

\section{KESIMPULAN}

Pada bab kesimpulan ini ditemukan 22 indikator yang bersifat antonim, 11 objek amatan, dan 2 kategori utama, yaitu: (1) metode desain dan (2) konsep desain. Metode desain memiliki 9 objek amatan dan 18 indikator, sedangkan konsep desain memiliki 2 objek amatan dan 4 indikator. Susunan kerangka penelitian dapat dilihat pada gambar 5.1.

Pada hunian arsitek akademisi A (dosen A) konsep desainnya berjenis rasional yang lazim disebut tipe glassbox. Konsep desainnya adalah (1) efisiensi bentukan ruang dan pola ruang; (2) optimasi struktur bangunan (3) tampilan bangunan geometris dan (4) bentuk bangunan anti main stream.

Pada hunian arsitek akademisi B (dosen B) konsep desainnya berjenis tradisional / konvensional yang lazim disebut tipe blackbox. Konsep desainnya adalah: (1) optimalisasi kontur eksisting; (2) optimasi struktur bangunan dan (3) tampilan bangunan anti main stream dan (4) bentuk bangunan anti main stream.

Pada hunian arsitek akademisi $\mathrm{C}$ (dosen $\mathrm{C}$ ) konsep desainnya berjenis gabungan yang lazim disebut tipe openbox. Konsep desainnya adalah: (1) maksimalisasi kenyamanan thermal tropis nusantara; (2) tampilan bangunan anti mainstream dan (3) bentuk bangunan berdasarkan analogi metafora intangible dari kapal layar.

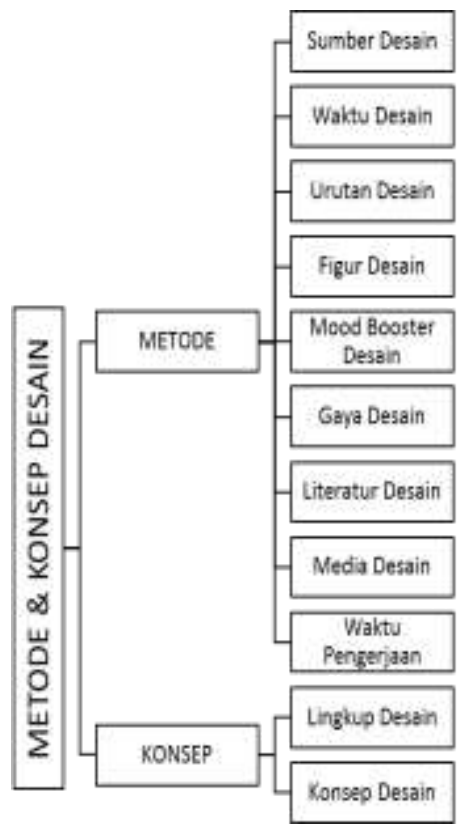

Gambar 13. Kerangka penelitian metode desain dan konsep desain Sumber: Analisis pribadi (2020) 


\section{DAFTAR PUSTAKA}

Ali, S. D. (2017). Design Thinking. https://sis.binus.ac.id/2017/12/18/designthinking-2/ (diakses 1 Februari 2019).

Cresswell, J. (2012). Eduactional Research: Planning, Conducting, and Evaluating Quantitative and Qualitative Research. Ney Jersey: Person Education, Inc.

Hindarto, P. (2017). 25 Karya Arsitek IAI Malang. Malang: IAI Malang dan Penerbit Kota Tua.

Hosein, A., Aczel, J., Clow, D., \& Richardson, J. (2008). Comparison Of Black-Box, Glass-Box And Open-Box Software For Aiding Conceptual Understanding for the Psychology of Mathematics Education, and the XX North American Chapter Vol. 1. Joint Meeting of the 32nd Conference of the International Group. Morelia, Michoacán: PME.

Jones, J. C. (1990). Developments in Design Methodology. New York: John Wiley \& sons Ltd.

Linden, J. C., Lacerda, A. P., \& Aguiar, J. P. (2011, Mei). The Evolution Of Design Methods. Tidak Diterbitkan. Universidade Federal do Rio Grande do Sul. Retrieved from https://www.researchgate.net/publication/273704768

Meilanita, J. (2017). Membangun Rumah Tahap 6: Konsep Desain. Retrieved from Arsitag: https://www.arsitag.com/article/tahap-6konsep-desain

Pena, W. M., \& Parshall, S. A. (2001). Problem Seeking: An Architectural Programming Primer. New York: John Willey and Son, Inc.

Taschen. (2009). Yes is More: An Archicomic on Architectural Evolution. Denmark: Bjarke Ingels Group (BIG). 
